\title{
EDITORIAL
}

\section{Psicologia, Religião e Vida MonÁstica}

Apesar da importância da questão religiosa, a psicologia científica tem tido dificuldade de abordar o assunto sem preconceitos, e até recentemente vem tratando a experiência religiosa como doença ou como ilusão. A psicologia acadêmica e a psicologia clínica mantêm distância desse ponto nevrálgico, manifestando diferentes formas de resistência e incompreensão sobre o fenômeno religioso, sem levar em conta a especificidade do sentido religioso, sua significação para os que a ela se referem, assim como sua importância histórica e social na formação humana e na elaboração e transmissão dos valores e ideais. Essa dificuldade da psicologia científica tem raízes históricas em sua luta contra o poder religioso, na intransigência religiosa diante do desenvolvimento das diferentes especialidades científicas e nos conflitos gerados na oposição entre ciência e religião, a partir do Renascimento e mais acentuadamente depois do século XIX.

Essa situação começou a mudar em meados do século XX, e atualmente os estudiosos da psicologia da religião aceitam que a experiência religiosa se distingue das demais experiências humanas, levando em conta a especificidade do sentido religioso e a relação com uma ordem sobrenatural distinta da ordem natural. Essa experiência é considerada como inerente ao mundo e à vida pessoal, mas ela implica também apreensões novas, surpreendentes e transformadoras (como na santificação e na iluminação) e um conhecimento específico da caminhada espiritual e da relação com Deus ${ }^{1}$.

As ciências sociais e humanas que estão pesquisando o assunto passaram a tratar a religião como uma realidade cultural distinta. Perceberam um centro de interesses comum no campo das religiões, permitindo estabelecer uma unidade entre os fenômenos identificados como religiosos. A psicologia, em particular, vem se esforçando, há mais de um século, por estudar a dimensão psicológica dos dados religiosos. Apesar da variação das significações e do sentido religioso entre os diferentes universos religiosos, esses pesquisadores propõem, portanto,

${ }^{1} \mathrm{~A}$ experiência mística constitui uma categoria particular de experiência religiosa, que se diferencia da experiência de tipo visionário, na qual predominam as visões e revelações privadas. Esse tipo de experiência brota no terreno da vida comunitária de uma tradição religiosa, resultando do aprofundamento da caminhada espiritual e da prática constante, nas quais os fenômenos de êxtase e as visões constituem apenas episódios. 
uma área específica de estudo, denominada psicologia da religião. Considerando a relação da religião com a cultura, procuraram descrever e entender a maneira como as pessoas percebem os enunciados religiosos, dentro do sistema simbólico no qual estão integrados, sendo a linguagem religiosa encarada como uma das faces do complexo universo simbólico. A psicologia da religião busca, então, esclarecer os significados e as intenções latentes da vivência religiosa, mostrando sua relação com a estrutura da religião, observando e interpretando as relações entre os elementos psicológicos e a religião. Independentemente da fé ou da crença pessoal de cada pesquisador desta área, propõe-se que o estudioso da religião coloque entre parênteses a questão do transcendente, não afirmando nem negando a realidade do divino ou o sobrenatural. Por não ser ela susceptível de verificação empírica, a negação ou comprovação dessa realidade escapa ao campo da ciência.

Assim sendo, a psicologia da religião não é um catálogo de pesquisas e pontos de vista sobre os diferentes componentes ou as práticas da religião, mas um ensaio de compreensão psicológica do homem religioso e da maneira de viver a existência em relação com o sobrenatural ou com Deus, levando em consideração tanto a vida dos grupos como as relações pessoais. Dizer que a religião é uma ideologia seria inadequado, pois para o homem religioso o divino não é uma ideia e não se ora ou não se fazem rituais para as ideias.

A relação com o divino se exprime e se realiza em ações e relações simbólicas, que impregnam a vida afetiva, nutrindo-se de relatos sobre os acontecimentos fundadores da religião e dando lugar a experiências religiosas. Isso não quer dizer que as ideias e as representações não desempenhem um papel importante na concepção religiosa, como também na concepção daqueles que não creem. Propõe-se, inclusive, que as representações de ambos (crentes e não crentes) sejam estudadas pela psicologia da religião, por considerá-las como diferentes tipos de resposta à questão do divino, que se relacionam num mesmo processo de formação, oposição e transformação.

Considerando que a ação humana não se apoia apenas na razão², mas em forças e processos psíquicos que têm sua própria lógica, alguns estudiosos da psicologia da religião procuram enfocar o psicológico nessa dimensão mais ampla e na relação desta com o divino. A psicóloga da religião não se reduz

\footnotetext{
2 Critica-se, contudo, a identificação da experiência religiosa com os sentimentos. Apesar da importância da intensidade afetiva da experiência religiosa, é preciso também o conhecimento do que é o religioso para que essa experiência tenha um sentido.
} 
apenas ao estudo da experiência religiosa, apesar do papel relevante que esta noção representa nesse campo. A importância deste tema decorre da tentativa de algumas teorias que, a partir do começo do século XX, procuram fundamentar o religioso num modo de conhecimento original. A propagação contemporânea do estudo desse modo de apreensão da realidade resulta também de uma maneira nova de abordar a diversidade da consciência, com ênfase no ser, na subjetividade e na consciência de si.

De qualquer forma, já existem psicólogos que reconhecem que algumas pessoas experimentam, desde a infância, um impulso para Deus. Essa relação com Deus muda a vida das pessoas e pode se expressar numa conversa e numa relação pessoal com o divino ${ }^{3}$. $\mathrm{Na}$ atualidade, é ainda mais importante estar em contato com os próprios impulsos e desejos, aprender a lidar com eles e a compreender o seu sentido espiritual. Para isso, contudo, é necessário praticar alguma forma de recolhimento e de contato consigo e com Deus, pois as mentes barulhentas e os ouvidos atentos aos sons externos não podem escutar o leve murmúrio do chamado divino vindo do âmago do ser. Este é um dos grandes desafios de nossa época, sobretudo, tendo em vista a proporção atingida pelos apelos externos e pela tendência à dispersão da mente e à multiplicação dos desejos.

Em conclusão, o sentido religioso da psique não pode ser reduzido a uma explicação meramente social e materialista, que não leve em conta a vida espiritual, assim como os sentidos e significações a ela atribuídos pelos que vivem essas experiências e os efeitos transformadores dessas experiências. Enquanto seres humanos contraditórios, os adeptos de um caminho espiritual podem ter várias falhas, limitações e variadas motivações, mas ao se engajarem numa busca espiritual passam por um processo particular de transformação e desenvolvem novos tipos de relação fraterna com os outros seres humanos. Os estudos desses processos e relações estão abrindo novos horizontes aos pesquisadores das ciências humanas e sociais. Eles podem ser realizados independentemente de qualquer convicção religiosa pela observação das características mentais e das relações comunitárias das pessoas mais profundamente engajadas no caminho espiritual e religioso, através de

3Os profetas bíblicos, por exemplo, narram as suas experiências e relatam como procuram discernir os chamados de Deus escutando os impulsos mais profundos de seus corações. 
indicadores 4 que apontam para uma nova ordem do mundo, podendo-se tornar uma inspiração para as novas gerações.

\section{Olga Sodré}

Psicóloga clínica (CRP - 5/6371). Doutora em filosofia (Paris - Sorbonne) e em psicologia clínica pela PUC - Rio. Tem um pós-doutorado em filosofia (Institut Catholique de Paris) e outro em saúde coletiva (Instituto de Medicina Social da UERJ), integrando atualmente o Grupo de Trabalho Psicologia e Religiãoda ANPEP -

Associação Nacional de Pesquisa e Pós-graduação. Foi consultora, pesquisadora e professora, em diversas instituições brasileiras e estrangeiras.

E-mail: olgasodre@gmail.com 4 Como, por exemplo: um mais alto nível de atenção, de equilíbrio dos impulsos, de paz mental, de
delicadeza de sentimentos, de respeito e gentileza com o outro, etc. 